\title{
CO-LIVING DENGAN KONSEP ECO-BUILDING UNTUK ERA PANDEMI HINGGA PASCA-
} PANDEMI

\author{
Nathanael Hizkia ${ }^{1)}$, Rudy Trisno ${ }^{21}$ \\ 1)Program Studi S1 Arsitektur, Fakultas Teknik, Universitas Tarumanagara, \\ natanael.315170110@stu.untar.ac.id \\ 2) Program Studi S1 Arsitektur, Fakultas Teknik, Universitas Tarumanagara, rudyt@ft.untar.ac.id
}

Masuk: 04-07-2021, revisi: 15-08-2021, diterima untuk diterbitkan: 23-10-2021

\begin{abstract}
Abstrak
Pandemi Covid-19 (coronavirus disease) yang masih berlangsung hingga saat ini sudah berdampak bagi semua aspek dan gaya hidup masyarakat secara global. Perubahan yang terjadi membuat adanya pergantian paradigma kehidupan, baik saat pandemi masih berlangsung, ataupun setelah pandemi berakhir. Melalui pandemi ini, masyarakat juga belajar bahwa rumah merupakan tempat yang penting bagi kehidupan, baik dengan segala kelebihan dan kekurangan yang ada di dalamnya. Proyek ini bertujuan memenuhi kebutuhan masyarakat akan tempat tinggal yang fleksibel dan tidak memberi kesan mengukung penghuni selama pandemi maupun setelah pandemi, dengan masih memperhatikan keamanan penghuni. Metode yang digunakan adalah dengan metode kualitatif dengan meneliti : teori ketahanan; dan teori eco-building. Kesimpulan akhirnya adalah proyek ini dimaksudkan untuk menyediakan apartemen co-living yang aman, nyaman, fleksibel, tanggap pandemi hingga pasca pandemi, dan bangunan yang menerapkan eco-building. Kebaruan yang ada pada proyek ini adalah menciptakan sebuah hunian yang bisa beradaptasi dengan keadaan saat pandemi maupun setelah pandemi dengan berkonsep eco-building.
\end{abstract}

Kata kunci: co-living; covid-19; eco-building; ketahanan; pandemi

\begin{abstract}
The Covid-19 pandemic (corona virus disease) which is still ongoing today has an impact on all aspects and lifestyles of people globally. The changes that have occurred have made a paradigm shift in life, both during the pandemic, or after the pandemic ended. Through this pandemic, people have also learned that home is an important place for life, both with all the advantages and disadvantages in it. This project aims to meet the community's need for a place to live that is flexible and does not give the impression of supporting residents of the pandemic and after the pandemic, while still paying attention to the safety of the residents. The method used is a qualitative method by examining: the theory of resilience; and green building theory. The final conclusion is that this project is available to provide co-living apartments that are safe, comfortable, flexible, responsive to pandemics to post-pandemic, and buildings that implement eco -building. The novelty in this project is to create a residence that can adapt to conditions during the pandemic and after the pandemic with eco-building concept.
\end{abstract}

Keywords: co-living; covid-19; eco-building; resilience; pandemic

\section{PENDAHULUAN}

Latar Belakang Isu

Pandemi Covid-19

Pada awal tahun 2020, coronavirus jenis baru, yaitu SARS-CoV-2 atau yang sering juga disebut Covid-19 (coronavirus disease) mulai menyebar. Virus ini diketahui berasal dari Wuhan, Tiongkok, dan pertama kali ditemukan pada akhir Desember 2019. Demi mencegah penularan, 
pemerintah Indonesia memberlakukan Pembatasan Sosial Berskala Besar (PSBB) pada 10 April 2020 dengan kota Jakarta menjadi kota pertama yang melakukan PSBB (Redaksi WE, 2020).

Sejak saat itu, Pemerintah Indonesia sudah melakukan berbagai upaya pencegahan untuk memutus rantai penyebaran Covid-19 seperti mewajibkan masyarakat untuk menjaga imunitas tubuh, menjaga kebersihan, memakai masker, menghindari kerumunan, memperbanyak minum air putih, dan lainnya (Farah \& Nasution, 2020).

Dengan diberlakukannya protokol kesehatan yang perlu ditaati, minat terhadap kegiatan di luar ruangan menurun. Menurut Anna Mueller (2020, Sosiologis, Indiana University Bloomington), pandemi telah mengajarkan masyarakat bahwa sistem pembelajaran secara daring merupakan sesuatu yang sangat efektif, dan memungkinkan hampir setiap murid bergabung tanpa mengalami kendala seperti bagi penyandang disabilitas. Namun, hal ini jua berdampak pada kesehatan mental murid yang perlu diperhatikan.

Sementara menurut John Barry (2020, Sejarawan, Tulane University), terjadinya pandemi akan mengubah cara manusia bekerja dan hidup, serta menjadikan kendaraan pribadi sebagai pilihan utama dibandingkan dengan transportasi publik dengan alasan kesehatan. Menurut Mario Luis Small (2020, Sosiologis, Harvard University) dan Christopher McKnight Nichols (2020, Sejarawan, Oregon State University), masyarakat akan mempertanyakan pentingnya pembelajaran secara langsung, alih-alih pembelajaran jarak jauh. Masyarakat juga akan sangat mencari dan menikmati aktifitas bersantai dan berkumpul setelah pandemi berakhir, (Bower, 2020)

Seorang arsitek dari Israel, Avner Yashar (2020) mengungkapkan bahwa lewat peristiwa pandemi, secara tidak langsung manusia belajar bahwa rumah tinggal merupakan sebuah komponen penting dalam kehidupan. Rumah dan hunian yang ada saat ini pun belum dapat mengantisipasi keadaan pandemi saat ini

\section{Perjanjian Paris UNFC Atas Perubahan Iklim}

Pada 12 Desember 2015, semua negara yang tergabung dalam UNFCCC berkumpul untuk membentuk sebuah perjanjian untuk melakukan sebuah upaya ambisius untuk memerangi perubahan iklim yang sedang terjadi serta beradaptasi dengan dampaknya. Tujuan utama dari Perjanjian Paris adalah untuk memperkuat respon dunia terhadap ancaman dari perubahan iklim dengan menjaga kenaikan suhu global abad ini jauh di bawah 2 derajat celcius dan untuk mengejar upaya membatasi kenaikan suhu mendekati 1 , derajat celcius. Selain itu, perjanjian tersebut juga bertujuan meningkatkan kemampuan negara-negara untuk menangani perubahan iklim serta dampaknya (United Nations Climate Change, 2015) .

Salah satu poin penting dalam perjanjian ini adalah target untuk tahun 2030, dimana "zerocarbon solutions" dapat diterapkan hampir ke seluruh sektor kehidupan yang mewakili 70\% dari emisi dunia secara global (United Nations Climate Change, 2015).

\section{Permasalahan}

Permasalahan yang terjadi adalah kurang tanggapnya hunian masa kini terhadap situasi pandemi yang sudah mengubah gaya hidup dan cara berhuni masyarakat hingga ke depannya. Dengan berubahnya gaya hidup, hunian sudah seharusnya dapat menyesuaikan dengan keadaan, baik saat pandemi maupun keadaan pasca-pandemi.

Permasalahan yang kedua dari hunian dan bangunan lainnya adalah bangunan masih belum memperhatikan permasalahan dari sisi lingkungan, khususnya bangunan di Indonesia. Sementara, menurut perjanjian Paris, per tahun 2030, bangunan sudah harus minim hingga tidak mengeluarkan emisi. (United Nations Climate Change, 2015). 


\section{Tujuan Proyek}

Tujuan dibangunnya proyek ini adalah memberikan sebuah tempat tinggal yang aman, fleksibel dan tidak memberikan kesan "mengukung" kepada penghuninya. Sebuah tempat tinggal yang tanggap pandemi harus memberikan fleksibilitas, privasi bagi penghuninya, memperhatikan kesehatan penghuni dan juga membangun sebuah bangunan yang mendukung gerakan "zerocarbon solutions" untuk tahun 2030 mendatang, sesuai dengan target Perjanjian Paris.

\section{KAJIAN LITERATUR}

\section{Lokasi}

Hunian Komunal berlokasi di Jl. Damai Foresta, BSD City, Serpong, memiliki ketentuan sebagai berikut :

$\begin{array}{lll}\text { Luas Tapak } & : 19.200 \mathrm{~m}^{2} \\ \text { KDB } & : 60 \% & : 11.520 \mathrm{~m}^{2} \\ \text { KLB } & : 3.5 & : 67.200 \mathrm{~m}^{2} \\ \text { KDH } & : 28 \% & : 5.376 \mathrm{~m}^{2}\end{array}$

\section{Pengertian Tentang Hunian Komunal}

Hunian Komunal (Co-Living) adalah sebuah hunian yang sangat cocok bagi kaum milenial yang membutuhkan alternatif hunian. Hunian ini hadir dengan biaya yang sangat terjangkau serta memiliki kelebihan dibandingkan menyewa apartemen sendiri. Konsep co-living sendiri mirip dengan konsep hunian indekos yang sudah terkenal di Indonesia. Bedanya adalah, ada bagian dan fasilitas bersama seperti dapur bersama, ruang kerja bersama, sehingga kegiatan yang dirancang bersama (Ochi, 2019). Co-Living juga menjadi salah satu solusi dalam mengatasi permasalahan seperti kekurangan jumlah hunian, hingga hunian yang belum memadai bagi penghuni dengan tren yang semakin berkembang. Berbagai faktor sosial ekonomi, seperti pernikahan yang ditunda, tren hidup mandiri bagi kaum milenial, menurunnya tingkat kepemilikan tanah akibat mahalnya harga tanah dan harga sewa, membuat co-living semakin diminati oleh masyarakat kota.

Hal ini terbukti dengan meningkatnya jumlah pencarian laman google mengenai hunian co-living dari tahun ke tahun (Gambar 1).

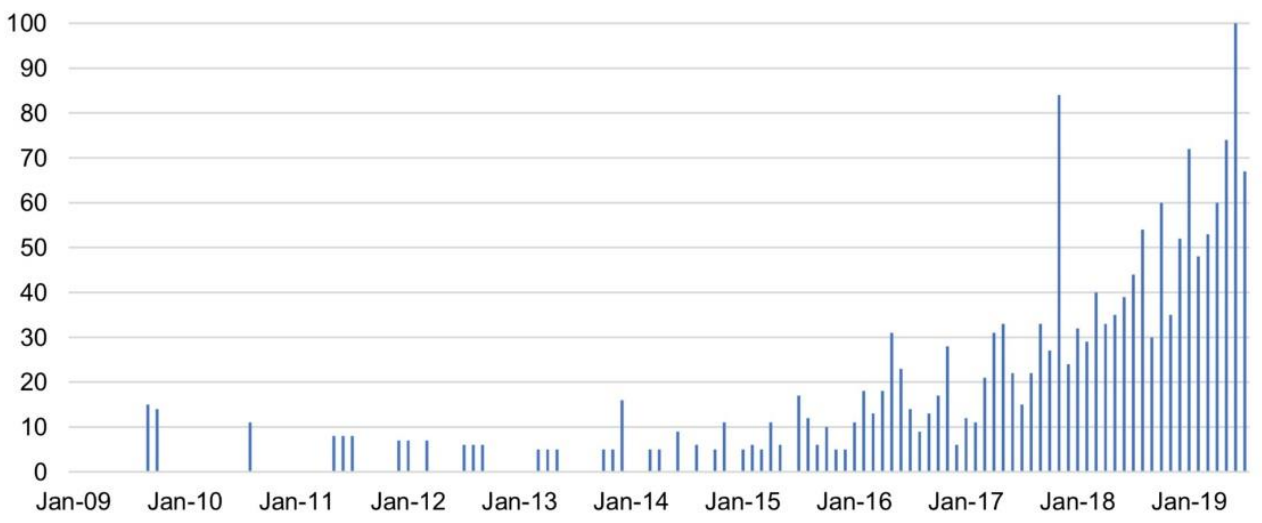

Gambar 1. Grafik jumlah pencarian co-living di laman google Sumber: Google Trends (2019)

Kenyamanan lainnya dalam co-living adalah sistem sewa yang lebih fleksibel bagi kaum milenial yang lebih mengedepankan sewa jangka pendek. Selain itu, kelebihan lainnya ada pada perabot rumah tangga yang sudah disediakan pemilik untuk digunakan bersama (Sam Pepper, 2019). 


\section{Pengertian Tentang Kaum Millenial}

Target pasar dari co-living yang adalah milenial, membuat hunian ini sangat diminati belakangan ini. Milenial sendiri merupakan sebuah kelompok demografi dari empat kohort besar (Baby Boomer, Gen-X, Milenial, dan Gen-Z). Kaum milenial merupakan mereka yang lahir pada tahun 1981-2000. Kaum milenial diperkirakan akan menjadi tulang punggung perekonomian negara, karena jumlahnya yang hampir mencapai $33 \%$ dari total penduduk Indonesia menurut data BPS. Artinya, per tahun 2015, kaum milenial mencapai jumlah 83 juta jiwa, dengan 47 juta diantaranya tinggal di pulau Jawa. Angka ini diperkirakan akan terus mengalami kenaikan (Arvian \& Surya, 2019).

Generasi Milenial memiliki sebuah pola pikir baru yang berbeda dari mereka yang lebih tua. Kaum milenial cenderung tidak nyaman berada di ruang yang konvensional, sehingga mereka membutuhkan sebuah tipologi ruang yang baru yang mengaburkan batas antara ruang kerja, ruang istirahat, dan ruang bersantai (Arvian \& Surya, 2019).

\section{Pengertian Tentang Ketahanan (Resilience)}

Menurut Reivich dan Shatte (2002) , resiliensi adalah kemampuan seseorang untuk beradaptasi terhadap kejadian berat atau masalah besar yang terjadi dalam kehidupan. Dalam proses individu mencapai resliensi terdapat dua faktor. Faktor tersebut adalah faktor resiko atau faktor yang dapat menghambat dan faktor protektif atau faktor yang dapat mendukung seseorang mencapai resiliensi (Reivich \& Shatte, 2002).

\section{Cara Hunian Menghadapi Pandemi}

Beberapa penelitian terbaru dari para ahli medis menyatakan bahwa sinar matahari tidak bisa membunuh virus Covid-19 yang ada di dalam tubuh maupun yang ada di luar ruangan. Ahli Alergi Imunologi Anak Indonesia Prof. Dr. Budi Setiabudiawan dr SpA(K) mengungkapkan bahwa sinar matahari dapat mencegah penularan virus Covid-19 melalui peningkatan imun tubuh. Salah satu vitamin yang berperan dalam menjaga daya tahan tubuh adalah vitamin $D$, yang dapat diperoleh dari sinar matahari berupa sinar ultraviolet B. Vitamin $D$ akan terserap tubuh saat sinar ultraviolet B mengenai permukaan kulit. (Pranita, 2020).

Tingkat penularan Covid-19 dapat meningkat bila berada di ruang tertutup dengan sistem pendingin udara sirkulasi ulang, karena ketika droplet terbang ke udara dan mengalami penguapan, partikelnya akan menjadi sangat kecil dan bebas berterbangan di udara, bahkan dapat bertahan hingga jarak puluhan meter, sehingga dibutuhkan ventilasi udara yang baik agar sirkulasi udara tidak berputar di dalam ruangan, sehingga resiko penularan dapat diminimalisir (Nugroho \& dkk., 2020) (Chaterine, 2020).

\section{Pengertian Tentang Eco-Building}

Eco Design atau yang juga sering disebut sebagai Green Design adalah sebuah gerakan berkelanjutan yang bertujuan menciptakan perancangan arsitektur, dari tahap perencanaan, pelaksanaan dan pemakaian material serta teknologi yang ramah lingkungan, serta penggunaan energi dan sumber daya yang efektif dan efisien. Istilah Eco Architecture sendiri merupakan istilah holistik yang masih luas dan mencakup semua bidang. Berbagai konsep Eco Design yang kontekstual diciptakan demi mencapai perancangan arsitektur yang selaras dengan perilaku alam serta berkonstribusi dalam melestarikan dan menjaga keberlangsungan sumber daya alam.

Prinsip Low Energy Design atau disebut juga sebagai Arsitektur Hemat Energi merupakan salah satu tipologi arsitektur hasil manifestasi dari Desain Sadar Energi (energy conscious design). Desain sadar energi merupakan salah satu paradigma arsitektur yang menekankan pada konservasi lingkungan global alami khususnya pelestarian energi yang bersumber dari bahan 
bakar tidak terbarukan (non renewable energy) dan yang mendorong pemanfaatan energi terbarukan (renewable energy). Sadar energi atau penghematan energi pada dasarnya adalah bukan mengurangi konsumsi energi, melainkan lebih efisien dalam mengkonsumsi energi. Arsitektur Hemat Energi berlandaskan pada pemikiran minimalisasi penggunaan energi tanpa membatasi/mengubah fungsi bangunan, kenyamanan dan produktifitas penghuninya dengan memanfaatkan sains dan teknologi modern. Dicapai melalui sinergi antara metode pasif dan aktif dengan material dan instrumen hemat energi. Salah satu konsep arsitektur yang mendukung gerakan hemat energi adalah konsep Zero Energy Building (ZEB). Konsep Zero Energy Building ( ZEB ) adalah suatu upaya yang lebih progresif dalam mengurangi pemborosan dalam pemakaian energi tak terbarukan dan emisi gas rumah kaca. Zero energy, populer dengan istilah Zero Energy Building (ZEB), muncul di Eropa sekitar tahun 1980-an, meskipun baru 15 tahun belakangan menjadi gerakan besar dalam arsitektur. ZEB mulai populer ketika permasalahan lingkungan merambah ke ranah arsitektur. Penghematan energi dalam bangunan bukan lagi persoalan menghemat energi semata, tetapi merupakan bagian penting memangkas emisi CO2. Secara harfiah Konsep Zero Energy Bulding diartikan sebagai "Bangunan Tanpa Energi". Konsep Zero Energy Building merupakan pemahaman tentang bangunan yang secara keseluruhan (net) tidak mengonsumsi energi yang bersumber dari listrik negara (PLN) maupun bahan bakar fosil. Dengan kata lain, ZEB merupakan konsepsi bangunan yang dapat mencukupi kebutuhan energinya sendiri dari sumber energi terbarukan, seperti matahari, angin, air, bahan bakar nabati, biomassa, dan biogas. ZEB Meskipun demikian, mengingat beberapa sumber energi terbarukan, seperti energi matahari dan angin, seringkali tergantung pada kondisi cuaca yang kadang kala tidak mendukung, konsep ZEB masih membuka kemungkinan penggunaan energi fosil pada saat tertentu (Magdalena \& Tondobala, 2016).

\section{METODE}

Metode yang digunakan adalah metode kualitatif dengan memperhatikan unsur :

\section{Ketahanan (Resilience)}

Ketahanan pada bangunan ditunjukkan dari kemampuan bangunan untuk beradaptasi dengan keadaan pandemi maupun setelah pandemi. Saat pandemi, bangunan akan menjadi bangunan yang tanggap pandemi, dan setelah pandemi berakhir, bangunan dapat menyesuaikan dengan gaya hidup masyarakat setelah pandemi, contohnya adalah gaya hidup berkumpul dan gaya hidup sehat.

\section{Eco-building}

Penerapan eco-building pada bangunan adalah untuk mengikuti Perjanjian Paris bagi seluruh dunia agar bangunan per 2030 sudah tidak mengeluarkan emisi dan energi, dimulai dari penghematan energi dan air. Prinsip eco-building yang digunakan pada bangunan ini adalah menggunakan ZEB dengan bantuan aplikasi berupa EDGE Buildings. Penggunaan aplikasi EDGE dapat membantu menghitung besaran energi dan air yang dihemat oleh bangunan.

\section{DISKUSI DAN HASIL}

Hunian Komunal berlokasi di JI. Damai Foresta, BSD City, Serpong, memiliki ketentuan sebagai berikut :

$\begin{array}{lll}\text { Luas Tapak } & : 19.200 \mathrm{~m}^{2} & \\ \text { KDB } & : 60 \% & : 11.520 \mathrm{~m}^{2} \\ \text { KLB } & : 3.5 & : 67.200 \mathrm{~m}^{2} \\ \text { KDH } & : 28 \% & : 5.376 \mathrm{~m}^{2}\end{array}$

Hunian ini dirancang dengan fasilitas-fasilitas seperti :

a. Unit hunian yang dibagi ke beberapa tipe, yaitu tipe studio $24 \mathrm{~m}^{2}$ dengan kapasitas untuk 1 orang (210 unit); tipe $36 \mathrm{~m}^{2}$ dengan kapasitas untuk 2 orang dengan 2 kamar (180 unit); tipe 
$48 \mathrm{~m}^{2}$ dengan kapasitas 4 orang dengan 2 kamar (165 unit). Tipe studio memiliki masa bangunan terpisah dengan 2 tipe lainnya.

b. Fasilitas pendukung seperti area kantin, minimarket, co-working sewa dan co-working untuk penghuni, laundry, plaza, taman dan area olahraga outdoor, dan kolam renang.

Masa kompleks bangunan didesain dengan memaksimalkan ruang terbuka di seluruh area demi mencegah penularan Covid-19, dan demi efisiensi energi. Hampir $80 \%$ lantai dasar adalah ruang terbuka dengan 3 masa bangunan, dan berpusat pada bagian co-working dan lobi utama (Gambar 2).

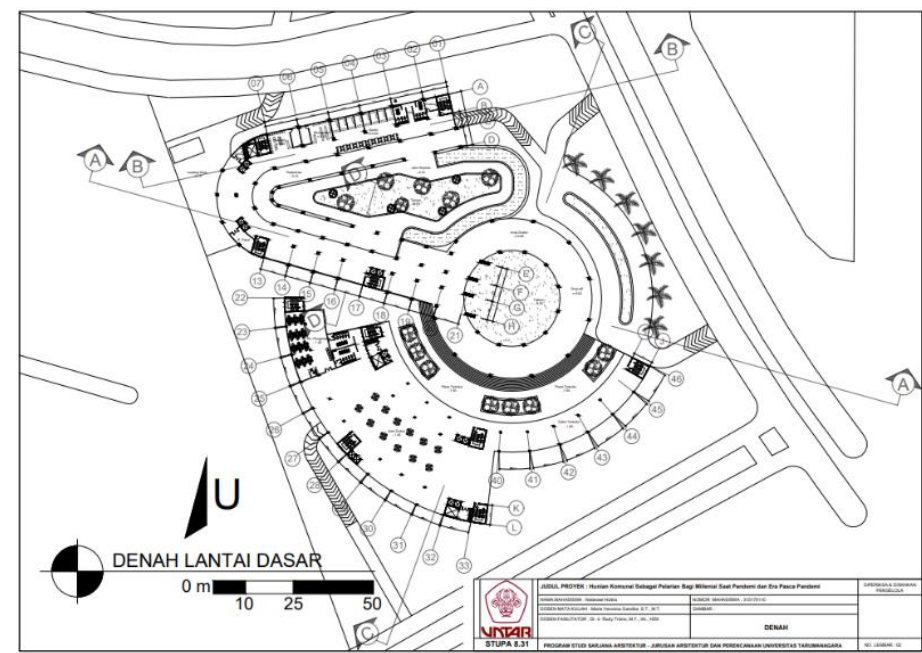

Gambar 2. Site Plan Bangunan

Sumber: Penulis (2021)

\section{Resilience}

Untuk mendapatkan hunian yang memiliki ketahanan terhadap situasi pandemi, dibuat beberapa skenario sirkulasi saat terjadi pandemi dan salah satu penghuni terpapar Covid-19.

Denah unit tipe 36, memiliki 2 skenario untuk menanggapi pandemi yang masih berlangsung. Karena tipe ini diisi dua orang dengan 2 kamar, maka jika salah satu penghuni terpapar virus, penghuni tidak perlu dipindahkan, melainkan tinggal menarik dinding partisi untuk segera memutus kontak dengan penghuni lainnya, dan dapat melakukan karantina mandiri.

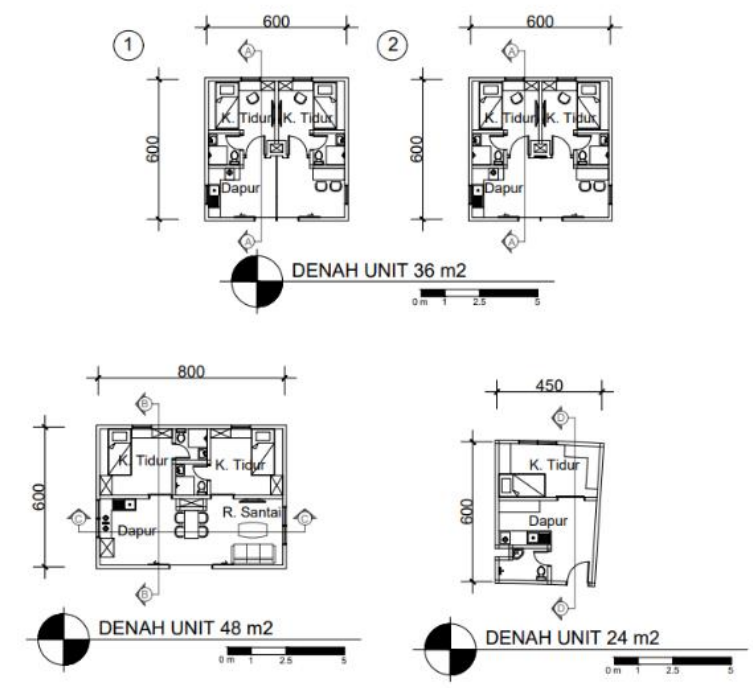

Gambar 3. Denah Unit

Sumber: Penulis (2021) 
Pada unit studio, penghuni dapat langsung melakukan karantina mandiri. Sementara untuk penghuni di tipe 48 , dapat dipindahkan ke unit studio yang kosong atau unit 36 yang dindingnya sudah disesuaikan. Semua tipe unit sudah didesain agar memiliki sirkulasi udara yang baik dan lancar (Gambar 3 \& Gambar 4).
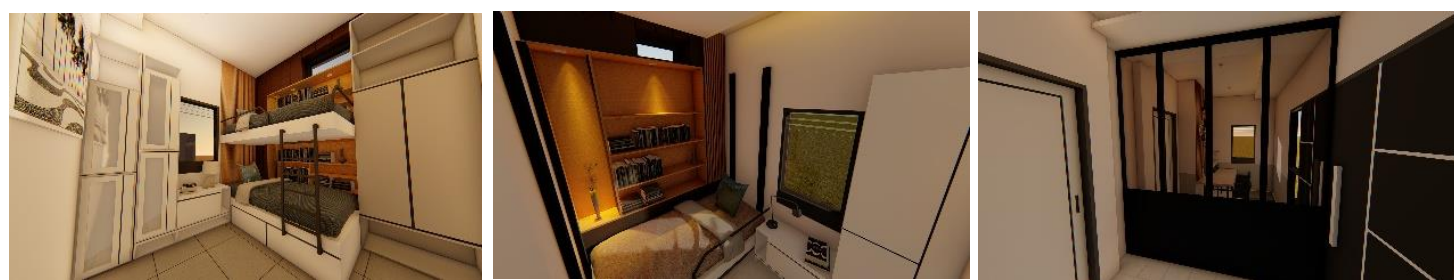

Gambar 4. Perspektif Interior Kamar Sumber: Penulis (2021)

Untuk mencegah penularan Covid-19, udara pada setiap unit dibuat mengalir secara lancar, terlebih pada unit yang diisi oleh dua orang atau lebih. Aliran udara dibuat sebisa mungkin tidak mengaliri banyak ruangan sekaligus, agar tidak terjadi penyebaran virus melalui udara. Setiap area dilengkapi dua ventilasi sekaligus, sehingga udara dapat mengalir secara lancar (Gambar 5).

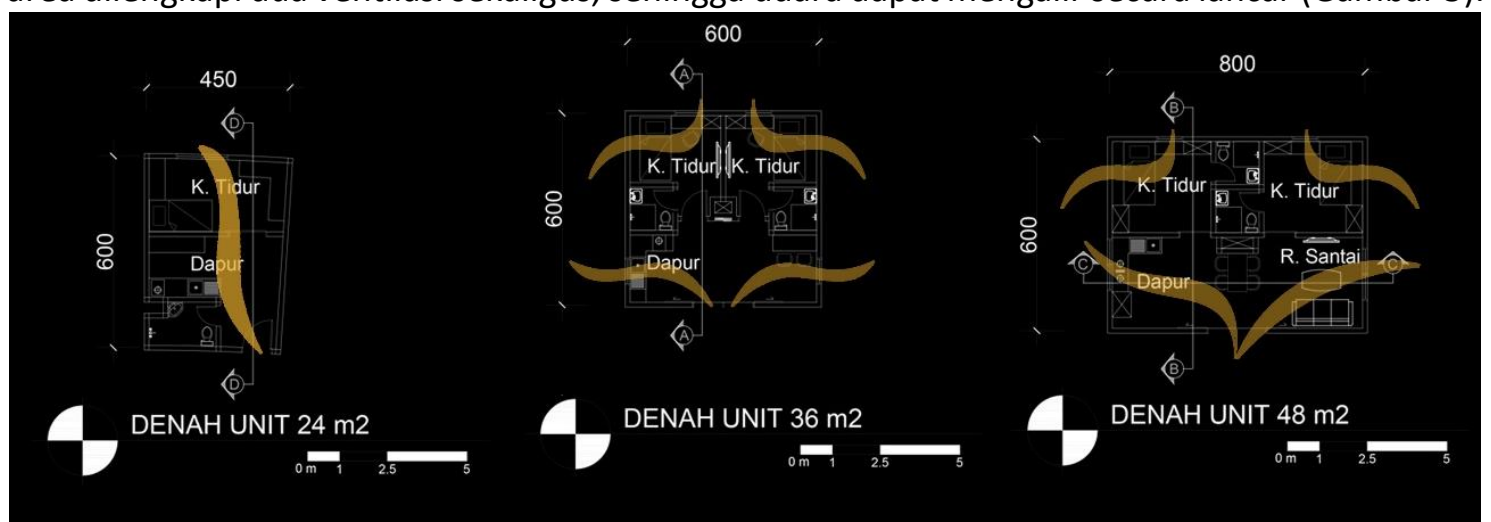

Gambar 5. Sirkulasi Udara di Unit Kamar

Sumber: Penulis (2021)

Koridor didominasi oleh ruang terbuka, sehingga udara dapat langsung mengalir melewati bangunan, dan udara yang mengaliri koridor adalah udara bersih. Dengan sirkulasi udara yang lancar, diharapkan dapat meminimalisir penyebaran Covid-19 selama pandemi berlangsung. Saat era pasca-pandemi, bangunan juga dapat menjadi bangunan yang sehat dan ramah lingkungan (Gambar 6).

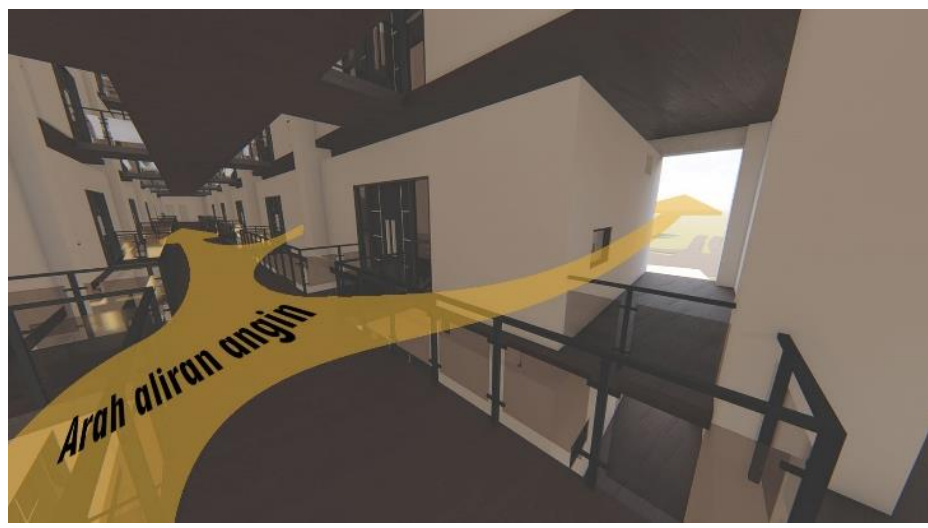

Gambar 6. Perspektif Koridor

Sumber: Penulis (2021) 
Jendela yang digunakan pada setiap unit adalah jendela khusus bernama Acoustic Friendly Ventilation Window, yang merupakan sebuah jendela khusus yang dapat digunakan pada bangunan tinggi. Jendela ini memiliki sebuah mesin ventilasi mekanikal yang dapat meningkatkan pertukaran udara bersih. Mesin ini mampu menghilangkan "polusi" udara hingga empat kali lebih baik dibanding jendela konvensional, dan mampu meningkatkan kenyamanan termal dengan konsumsi energi minimal. Pada masa pandemi, jendela ini mampu menurunkan kemungkinan penyebaran virus dengan terus melakukan perputaran udara bersih, bahkan saat ruangan menggunakan pendingin ruangan (Gambar 7).

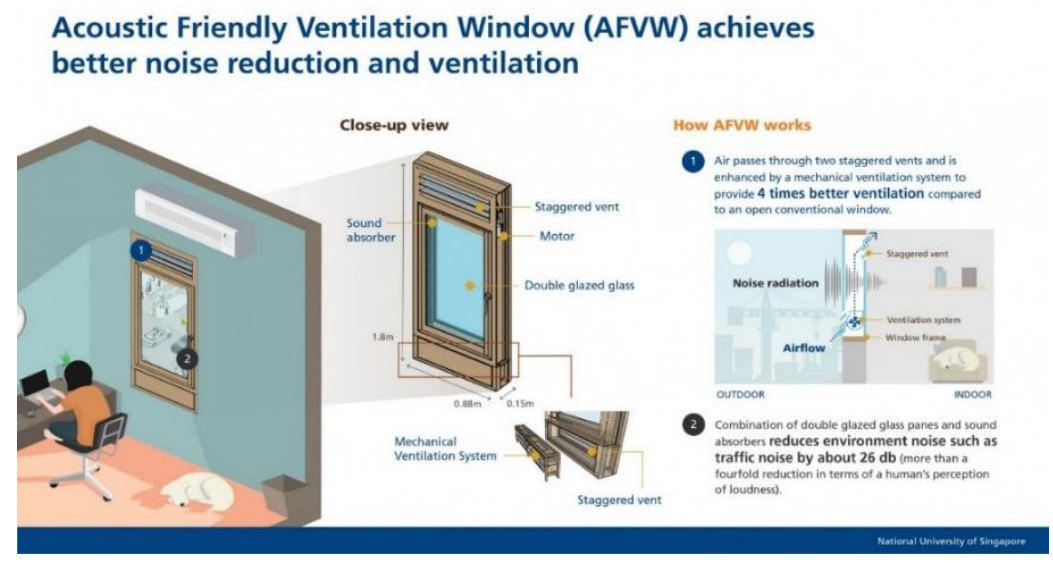

Gambar 7. Jendela AFV

Sumber: https://news.nus.edu.sg/novel-window-design-reduces-outdoor-noise-andimproves-ventilation/ (2021)

Dengan desain dari setiap ruangan yang mementingkan aliran udara dan pencahayaan matahari, bangunan dapat meminimalisir penyebaran virus Covid-19. Ketahanan bangunan ini tidak akan berakhir saat pandemi berakhir. Semua unsur tersebut akan menjadikan bangunan menjadi bangunan yang sehat dan mampu memadai kebutuhan gaya hidup berkumpul serta gaya hidup sehat bagi penghuninya setelah pandemi berakhir.

\section{Eco-Building}

Selain membangun sebuah bangunan yang memiliki ketahanan terhadap keadaan pandemi dan setelah pandemi, bangunan juga didesain mengikuti target lingkungan berdasarkan Perjanjian Paris untuk menjadikan bangunan mengeluarkan sesedikit mungkin emisi, hingga mendekati nol. Pada masa utama bangunan bagian utara memiliki second skin yang dapat berguna sebagai photovoltaics untuk membantu suplai energi terbarukan dari panel surya yang ada di atap bangunan (Gambar 8).

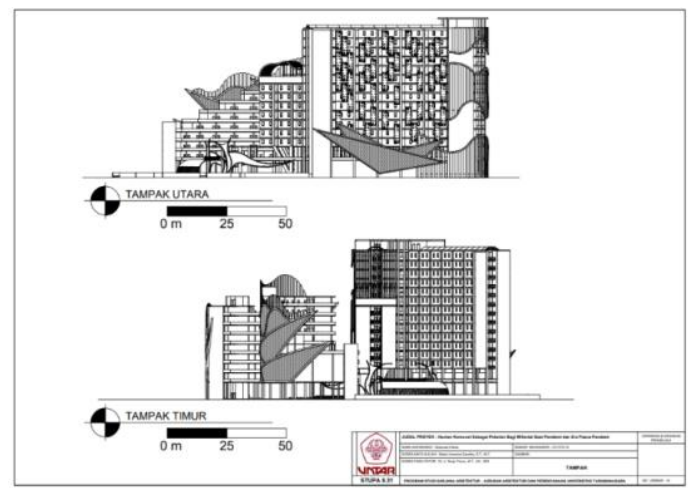

Gambar 8. Tampak Bangunan

Sumber: Penulis (2021) 
Bangunan menggunakan sekitar $40 \%$ energi terbarukan dari total pemakaian tahunan, yang sisanya menggunakan suplai energi dari PLN. Dengan menggunakan energi terbarukan, selain menjadikan bangunan ramah lingkungan, hal ini dapat mengurangi biaya yang dikeluarkan penghuni. Sistem bangunan juga menggunakan sistem daur ulang air kotor, sehingga air kotor diolah dan masih dapat digunakan untuk menyiram toilet atau menyiram tanaman.

Untuk mendukung desain bangunan yang efisien dalam hal energi, digunakan aplikasi Edge untuk menghitung efisiensi energi pada bangunan berdasarkan sistem yang dipakai di bangunan, seperti sistem air yang efisien, sistem listrik yang efisien dan berkelanjutan, dan material yang ramah lingkungan (Gambar 9 ).

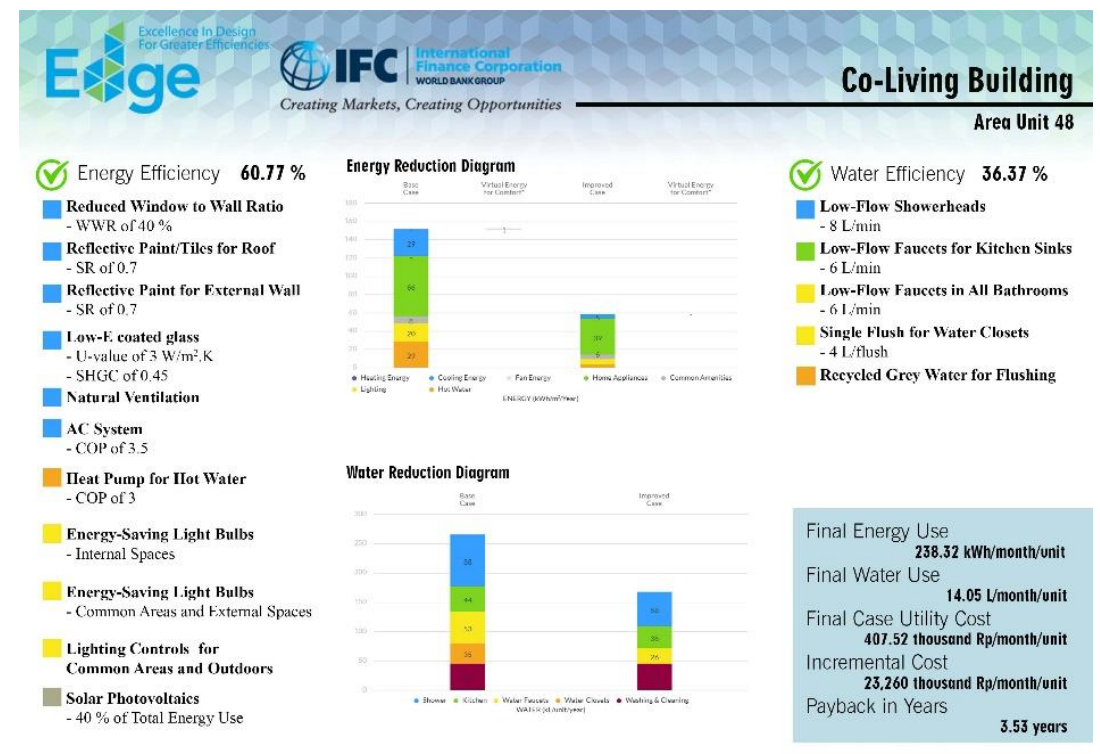

Gambar 9. Perhitungan Energi Berdasarkan EDGE Sumber: edgebuildings.com

Dari ketiga masa bangunan, didapat rata-rata dari energi yang dihemat adalah sekitar 58,45 \%, dan air yang dihemat sekitar 35,97 \% dari bangunan pada umumnya (EDGE Buildings, 2021). Dengan menggunakan aplikasi EDGE, dapat ditentukan bahwa bangunan ini sudah mencapai standard sebagai bangunan yang hemat energi dan hemat air. Hal ini dapat membantu dalam mencapai Perjanjian Paris untuk tahun 2030 dimana bangunan dapat mengurangi emisi yang dihasilkan sedikit demi sedikit hingga mencapai nol pada tahun 2030.

\section{KESIMPULAN}

Bangunan ini menggunakan metode ketahanan dan eco-building. Bangunan didesain untuk beradaptasi dengan keadaan pandemi maupun keadaan setelah pandemi. Saat pandemi, bangunan dapat bertahan dan dapat meminimalisir kemungkinan penyebaran virus Covid-19. Di dalam unit 36, terdapat dinding yang dapat ditarik ketika salah satu penghuni terpapar virus dari luar. Penyebaran virus lewat udara juga dapat diminimalisir dengan memaksimalkan ruang terbuka dan perputaran udara bersih dari luar ke dalam unit. Hal ini dapat membuat bangunan menjadi tanggap terhadap pandemi dan juga dapat menyesuaikan gaya hidup pasca-pandemi bagi penghuninya. Bangunan juga didesain agar pemakaian energi dapat seefisien mungkin serta berkelanjutan, dengan bantuan aplikasi EDGE untuk menentukan besaran energi dan besaran air yang dihemat oleh bangunan. Rata-rata penghematan energi adalah sebesar 58,45 $\%$, sementara air dapat dihemat hingga 35,97 \%, sehingga bangunan dapat dikategorikan sebagai bangunan hemat energi. Dengan begitu, bangunan dapat mulai menjalani Perjanjian Paris 2030 untuk bangunan nol emisi. 


\section{REFERENSI}

Arvian, A., \& Surya, R. (2019). Tempat Bekerja dan Tinggal Untuk Kaum Milenial. Jurnal STUPA, 01(02), 1413-1424. doi:dx.doi.org/10.24912/stupa.v1i2.4449

Bower, B. (2020, Desember 18). What WIII Life Be After Coronavirus Pandemic Ends? (Science News) Retrieved Februari 18, 2021, from https://www.sciencenews.org/article/covid19-coronavirus-life-after-pandemic-ends-predictions

Chaterine, R. N. (2020, Juli 11). Pakar Epidemeiologi: Penyebaran Corona Beresiko Lebih Tinggi di Ruang Tertutup. (detikNews) Retrieved November 24, 2020, from https://news.detik.com/berita/d-5089248/pakar-epidemiologi-penyebaran-coronaberesiko-lebih-tinggi-di-ruang-tertutup/1

EDGE Buildings. (2021). edgebuildings.com. Retrieved July 2, 2021, from https://app.edgebuildings.com/?_ga=2.181070247.1261538587.16253181161015421483.1614498789

Farah, B., \& Nasution, R. D. (2020). Analisis Perubahan Orientasi Pola Hidup Mahasiswa Pasca Berakhirnya Masa Pandemi Covid-19. Noken Journal, 5(2), 24.

Magdalena, E., \& Tondobala, L. (2016). IMPLEMENTASI KONSEP ZERO ENERGY BUILDING (ZEB) DARI PENDEKATAN ECO-FRIENDLY PADA RANCANGAN ARSITEKTUR. Media Matrasain, 13(1), 2-3.

Nugroho, W. D., \& dkk. (2020). Transmisi Covid-19 dari Manusia ke Manusia di Asia. Journal of Blonursing, 2(2), 109.

Ochi, E. (2019). Mengenal Co-Living, Hunian dengan Konsep Berbagi yang Menjawab Kebutuhan Generasi Milenial. Retrieved 06 28, 2021, from https://journal.sociolla.com/lifestyle/mengenal-co-living

Pranita, E. (2020, Juli 25). Ini Penjelasan Ahli Soal Hubungan Sinar Matahari dan Virus Corona. (Kontan.co.id : Penyakit Menular) Retrieved November 24, 2020, from https://kesehatan.kontan.co.id/news/ini-penjelasan-ahli-soal-hubungan-sinarmatahari-dan-virus-corona?page=all

Redaksi WE. (2020, April 10). Anies : Jakarta Jadi Kota Pertama Terapkan PSBB. (Warta Ekonomi.co.id Perspektif Baru Bisnis \& Ekonomi) Retrieved November 24, 2020, from https://www.wartaekonomi.co.id/read280515/anies-jakarta-jadi-kota-pertamaterapkan-psbb

Reivich, K., \& Shatte. (2002). The Resilience Factor : Seven Essential Skill for Overcoming Life's Inevitable Obstacle. New York: Random.

Sam Pepper, A. M. (2019). Co-Living as an Emerging Market: An Assessment of Co-Living's Long-Term Resiliency. Massachusetts Institute of Technology, 01(01), 08-13.

United Nations Climate Change. (2015). The Paris Agreement. Retrieved July 3, 2021, from https://unfccc.int/process-and-meetings/the-paris-agreement/the-paris-agreement 